\title{
Sumac (Rhus Coriaria L.) and Ginger (Zingiber Officinale) as Feed Additive in Poultry Nutrition
}

\author{
Yadgar Ghali SALIH, Yavuz GURBUZ* \\ KSU, Faculty of Agriculture, Department of Animal Science, Kahramanmaras, Turkey
}

\author{
Received (Geliş): 09.03.2015
}

Accepted (Kabul): 17.09.2015

\begin{abstract}
In the last decade, there has been growing interest in the use of natural herbs and medicinal plants as feed additives in poultry diets to maximize their potential output. The European Union banned the use of antibiotic feed additives and the scientists are trying to find alternatives, one of the best options is herbs. Researchers particularly look for medicinal herbs that can affect such parameters as growth or treatment of certain diseases. .Medicinal plants have been used in poultry diets as feed additives to increase poultry performance, health and the quality of their products and their extracts have been tested in the diets of poultry as potential alternatives to antibiotics on growth promotion. Also, poultry has seen the greatest increase in production and gain, this trend will likely continue. Both poultry meat and eggs are well positioned to meet demands for increased supply from our growing world population. The interest to use the medical plants is mainly due to safety and healthy for human and less cost of herbs compared with synthetic chemical drugs and some of them decrease the level of serum lipids and lead to improve immune function in humans and also for animals. Therefore, The aim of this review is to evaluate information on the use of medical herbs including Sumac (Zingiber officinale) and Ginger (Rhus coriaria L.) as feed additives, with the emphasis on to improve poultry performance (laying hens and broiler). However, a systematic approach toward the efficacy and safety of phytogenic compounds used as feed additives for poultry is still lacking.
\end{abstract}

Key Words: feed additive, ginger, poultry nutrition, sumac

\section{INTRODUCTION}

The industrialization of poultry husbandry and the improvement of feed nutritional efficiency have accelerated the introduction of feed additives which became widely used in animal feed for many decades. The objective outlined by scientists, is to increase production (eggs, meat) while maintaining animals in good health. The use of antibiotics in poultry feed as a growth promoter is beneficial in improvement of production parameters and diseases prevention. However this large utilization has led to the increasing resistance of pathogens to antibiotics and the accumulation of antibiotic residues in animal products and in the environment. This situation requires the world to restrict using antibiotic growth promoters in animal feed (Nisha, 2008). Keeping farm animals healthy is necessary to obtain healthy animal products. For the last decade the use of additives of natural origin in animal and human nutrition has been encouraged. Numerous researches focused on the clarification of the biochemical structures and physiological functions of various feed additives like probiotics, prebiotics, organic acids and plant extracts. Herbs, spices and their extracts were already used thousands of years ago in Mesopotamia, India, China and old Greece, where they were appreciated for their specific aroma and various medicinal properties (Greathead, 2003). The effects expected of herbs and plant extracts are also various: the herbs and plant extracts act on the appetite and intestinal microflora stimulate the pancreatic secretions to increase endogenous enzyme activity and immune system. Many plant products and their constituents have a broad antimicrobial activity, antioxidant and sedative properties.Besides, scientists recently discovered that the appetizing and stimulating activity of herbs and plant extracts on animal digestive and immune system could benefit performance and health of farm animals (Lopez-Bote et al., 1998) Herbal extracts supplements have shown to have beneficial effects on broiler performance and carcass quality (Schleicher et al., 1998) A variety of herbal supplements have been widely used to maintain and improve health of humans (Freeman et al,. 1995) and birds (Gardzielewska et al., 2003) Herbal extracts can also improve immune system and reduce blood cholesterol (Mathivanan et al., 2007) The objective of this review is to examine the possibility of using herbs and their extracts as natural alternatives including Sumac and Ginger to replace antibiotic growth promoters in poultry fee.

\section{HERBAL PLANTS PROPERTIES}

Antimicrobial (Guo et al., 2004a), antioxidant (Hashemi et al., 2009a), anti-stress (Chattopadhyay et al., 2005), gut microflora manipulation (Hashemi et al., 2009b), nutrigenomics effect (Franco-Jimenez et al., 2007) and immune enhancement (Guo et al., 2004b) properties probably are the major mechanisms by which herbal plants exert positive effects on the growth performance and health of animals (Fig. 1). 


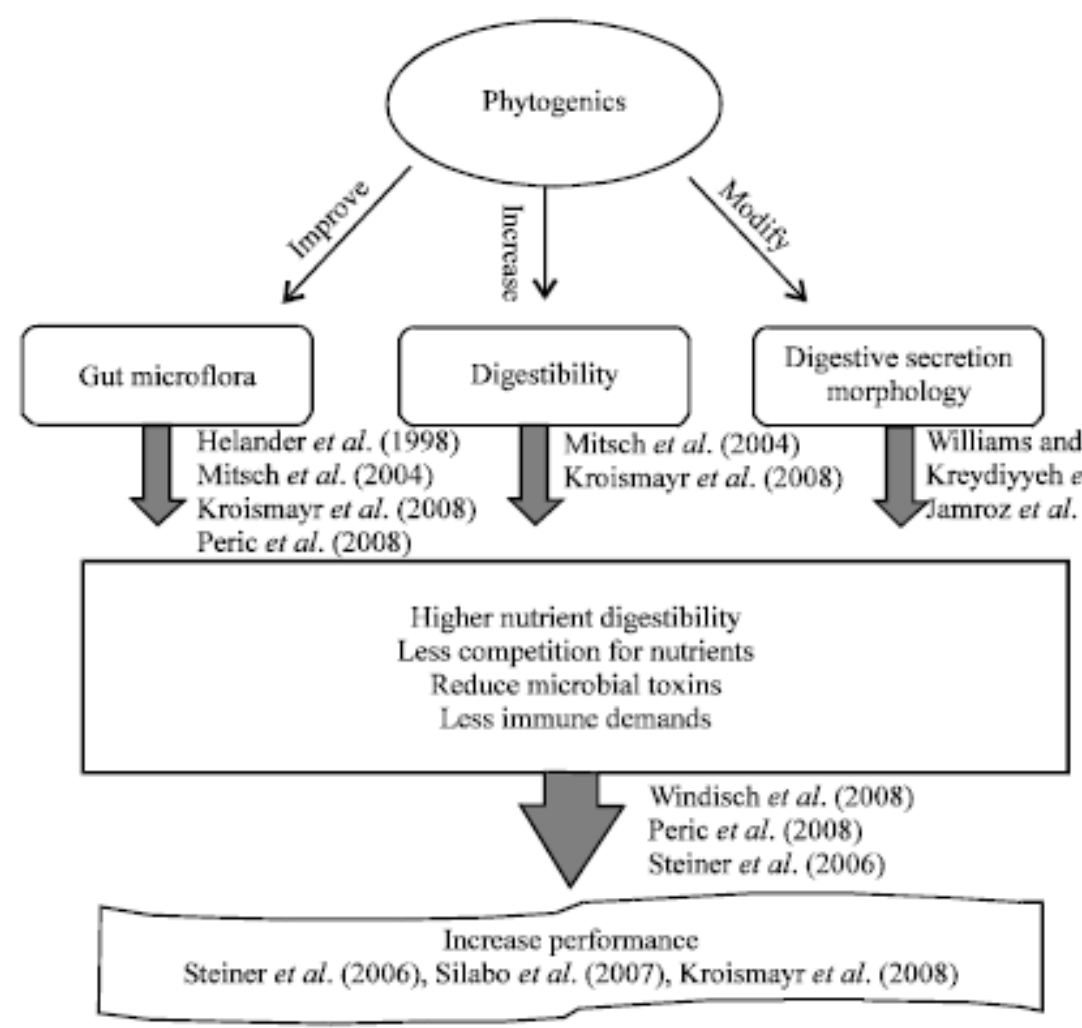

Fig. 1: Main mechanisms of herbal plants exert positive effects on the growth performance and health of animals. Tobias Steiner, BIOMIN GmbH, Herzogenburg, Austria with some modification

\section{Herbal or Phytogenic Feed Additives}

Herbs and plant extracts used in animal feed, called today phytogenic or herbal feed additives are defined as compounds of plant origin incorporated into animal feed to enhance livestock productivity through the improvement of digestibility, nutrient absorption and elimination of pathogens residents in the animal gut (Athanasiadou et al., 2007).

The large variety of plant compounds used as herbal feed additives are assembled according to their origin and treatment, such as herbs and spices (e.g. garlic, anise, cinnamon, coriander, oregano, chili, pepper, rosemary and thyme) but also essential oils or oleoresins (Kamel, 2000). The content of active substances in these products can vary greatly depending on what part of the plant is used (grains, leaves, roots, bark, flowers, or buds), the harvest season and geographical origin. The technique of treatment (cold, steam distillation, extraction) also changes the active substances and related compounds in the final product (Windisch et al., 2008). In the EU, these feed additives must demonstrate the identity and traceability of the entire commercial product, the claimed nutritional effects in addition to proofs of absence of interaction with other compounds. They must be tolerated by the animals, the users (farmers, manufacturers of animal feed) and the environment (European Commission, 2003). Modern intensive poultry production has achieved phenomenal gains in the efficient and economical production of high quality and safe chicken meat, eggs and poultry bioproducts. At the same time as making gains in production and efficiency, the industry has had to maximize the health and well-being of the birds and minimize the impact of the industry on the environment. Most additives are used to improve physical diet characteristics, feed acceptability or bird health.

\section{Effects of herbal feed additives on production performances}

The inclusion of anise seeds at a level of $0.5-0.75 / \mathrm{kg}$ corn-soybean-meal diet administered to broilers during 6 weeks, improved their body weight gain, performance index and relative growth rate. In contrast, a higher inclusion level of anise seeds $(1.5 \mathrm{~g} / \mathrm{kg}$ diet $)$ reduced growth performance (Soltan et al., 2008). Garlic (Allium sativum), thyme (Thymus vulgarus) and coneflower (Echinacea purpurea) as feed supplements have recently been reported to exert a wide range of beneficial effects on the production performance (weight gain, feed conversion, egg production and quality) of broilers and laying hens (Khan et al., 2012). Bolukbasi and Erhan, (2007) studied the effect of dietary Thyme supplementation with thyme on performance of laying hens and E. coli concentrations in their feces. Addition to basal diet at the level of 0.1$0.5 \%$ have given an improvement in feed conversion and egg production associated to a decline of E.coli concentration in feces. Effect of herbal feed additives on 
egg quality traits, such as yolk composition, shell thickness or Haugh unit rating, were reported in a few studies only, whereas the majority of reports did not identify substantial effects (Navid et al., 2013)

Ginger (Zingiber Officinale $)$ as Feed Additive in Poultry Feed

The production of poultry products, such as eggs and meat has been sustained with the use of antibiotics and growth promoters, used at therapeutic doses in animal feeds in order to improve the quality of the products (NOAH, 2001). Birds raised with these feed additives achieved good performance, their potential side effects present a real public health problem worldwide (Donoghue, 2003),that led to the ban of these products by European Union in January 2006. This decision has therefore stimulated a search for natural alternative feed additives, such as ginger, sumac and onion etc. Ginger root contains a number of compounds that exert varying biological activities, including antioxidant (Rababah, et al., 2004), antimicrobial (Jegetia et al., 2003), and various pharmacological effects (Ali et al., 2008). Ginger has been found to enhance pancreatic lipase activity (Platel and Srinivasan, 2000), intestinal lipase, disaccharides, sucrose and maltase activities of rat (Platel and Srinivasan, 1996). All of these have favorable effects on gut function, which is the primary mode of action for growth promoting feed additives (Windisch et al., 2008). The use of feed additives, such as ginger and garlic in livestock feed and human diets are becoming more popular, because of their beneficial health and preservative importance (Joke and Susan, 2007). Powdered rhizome of Ginger is one such potential rhizome with a wide range of medicinal effects. In broilers and layers, this plant has been used in different forms, doses and durations.

\section{Sumac (Rhus coriaria L.) as feed additive in poultry feed}

Sumac (Rhus coriaria L.) belongs to Anacardiaceous family and it grows widely in Asian countries. Traditionally, sumac has been used as medicine (Lee et al., 2003) for the treatment of gastritis, stomach cancer and arteriosclerosis (Jung, 1998) and for the protection of antiquities (Kim, 1996). The main compounds in sumac are tannins and substantial amounts of flavonoids (Zalacain et al., 2003). However, sumac is rich in B vitamins and Gallic acid (Gálik, 2012) reported that from nutritional point of view, (Rhus coriaria L.)seeds are rich in Gallic acid, benzoic acid anthocyanin (Guvenc and Koyuncu, 1994), flavones, such as myricetin, quercetin and kaempferol (Mehrdad, 2009), nitrite and nitrate contents (Ozcan and Akbulut, 2007). The seeds of Rhus coriaria L. are consequently, dietary supplementation of $0.5 \%$ sumac fruit powder can be effective to attenuate the negative effects of mild heat stress on broiler chickens and improve the performance during the first 21 days of age. Higher sumac fruit powder level (1\%) did not affect the performance during the starter period due to having more tannin. Moreover, dietary sumac fruit powder could not obviate the deleterious effects of intensive heat stress $\left(32^{\circ} \mathrm{C}\right)$ during the grower or whole the experimental periods (Alishah et al., 2013).

\section{CONCLUSIONS}

There are many advantages of using herbs than antibiotics and Medicinal herbs have been used since a very long time, but empirically. General mechanisms of action were little known in poultry and animals. Medical herb feed additives including sumac and ginger are good alternatives to replace antibiotic growth promoters. There are so many advantages of using herbs than antibiotics. Phytogenic feed additives may have the potential to promote production performance and productivity and thus, add to the set of non-antibiotic growth promoters such as organic acids and probiotics. Antibiotics can't be used during laying period of chickens due to residual effect in eggs. Nowadays, few herb products are available in market. Farmers can easily use in their layer, broiler and parent stock without any residual effect. Even these herbs can be used during the laying period. Farmers also interested to use the herbs for their poultry. But products are not still familiar to the farmers.

\section{REFERENCES}

Aji, S.B., Ignatuius, K., Ado, A.Y., Nuhu, J.B., Abdulkarim, A., 2011. Effect of feeding onion (Allium cepa) and garlic (Allium sativum) on some performance characteristics of broiler chickens. Res. J. Poult. Sci. 4: 22-27.

Aksit, M., Goksoy, E., Kok, F., Ozdemir, D., Ozdogan, M. 2006. The impacts of organic acid and essential oil supplementations to diets on the microbiological quality of chicken carcasses. Arch. Geflugelkd. 70:168-173.

Alishah, A.S., Daneshyar, M., Aghazadeh, A., 2013. The Effect of Dietary Sumac Fruit Powder (Rhus Coriaria L.) on Performance and Blood Antioxidant Status of Broiler Chickens under Continuous Heat Stress Condition. Italian Journal of Animal Science, 12 (1):39-43.

Allen, P.C., Lydon J., Danforth, H.D. 1997. Effects of components of Artemisia annua on coccidian infections in chickens. Poult. Sci. 76 (8):1156-1163.

Alloui, M.N., Szczurek, W., Świątkiewicz, S. 2013. The usefulness of prebiotics and probiotics in modern poultry nutrition. Ann. Anim. Sci. 13 (1): 17-32

Alloui, N., Ben Aksa, S., Alloui, M.N. 2012. Utilization of fenugreek (Trigonella foenum-graecum) as growth promoter for broiler chickens. J. World Poult. Res. 2(2):25-27.

Arczewska-Wlosek A., Swiatkiewicz, S. 2012. The effect of a dietary herbal extract blend on the 
performance of broilers challenged with Eimeria oocysts. J. Anim. Feed Sci., 21: 133- 142.

Athanasiadou, S., Githiori, J., Kyriazakis, I. 2007. Medicinal plants for helminthes parasite control: facts and fiction. Animal, 1 (9):1392-1400.

Balunas, M.J., Kinghorn, A.D. 2005. Drug discovery from medicinal plants. Life Sci. 78(5):431-441.

Basmacioglu, H., Tokusoglu, O., Ergul, M. 2004. The effect of oregano and rosemary essential oils or alpha-tocopheryl acetate on performance and lipid oxidation of meat enriched with n-3 herbal feed additives in broilers. S. Afr. J. Anim. Sci. 34:197210.

Bolukbaşi, S.C. Erhan, M.K., 2007. Effect of dietary thyme (Thymus vulgaris) on laying hens performance and E. coli concentration in feces. Int. J. Nat. Eng. Sci. 1(2): 55-58.

Botsoglou, N.A., Florou-Paneri, P., Christaki, E., Fletouris, D.J., Spais, A.B. 2002a: Effect of dietary oregano essential oil on performance of chickens and on iron-induced lipid oxidation of breast, thigh and abdominal fat tissues. Br. Poult. Sci. 43(2):223230.

Botsoglou, N.A., Florou-Paneri, P., Christaki, E., Fletouris, D.J., Spais, A.B. 2002b. Effect of dietary oregano essential oil on lipid oxidation in raw and cooked chicken during refrigerated storage. Meat Sci. 62:259-265.

Botsoglou, N.A., Grigoropoulou, S.H., Botsoglou, E., Govaris, A., Papageorgiou, G. 2003. The effects of dietary oregano essential oil and [alpha]-tocopheryl acetate on lipid oxidation in raw and cooked turkey during refrigerated storage. Meat Sci. 65: 11931200 .

Botsoglou, N.A., Christaki, E., Florou-Paneri, P., Giannenas, I., Papageorgiou, G., Spais, A.B. 2004. The effect of a mixture of herbal essential oils or alpha-tocopheryl acetate on performance parameters and oxidation of body lipid in broilers. S. Afr. J. Anim. Sci. 34: 52-61.

Christaki, E., Florou-Paneri, P., Giannenas, I., Papazahariadou, M.A., Botsoglou, N.A., Spais, A.B. 2004. Effect of a mixture of herbal extracts on broiler chickens infected with Eimeria tenella. Anim. Res. 53: 137-144.

Chrubasik, S., Pittler, M.H., Roufogalis, B.D. 2005. Zingiberis rhizome: A comprehensive review on the ginger effect and efficacy profiles. Phytomedicine, 12: 684-701.

Cosentino, S., Tuberoso, C.I.G., Pisano, B., Satta, M., Mascia, V., Palmas, F.1999. In vitro antimicrobial activity and chemical composition of Sardinian thymus essential oils. Lett. Appl. Microbiol. 29: 130-135

Craig, W.J. 1999. Health promoting properties of common herbs. Am. J. Clin. Nutr. 70 (Suppl.): 491499. Cuppett, S.L., Hall, C.A. 1998. Antioxidant activity of Labiatae. Adv. Food. Nutr. Res. 42: $245-$ 271.

Daas Amiour W., Bouzdi, S., Djemai Zoughlache, K., Boudjellal, K., Abdessemed, H. 2009. Antibacterial activity of some fruits; berries and medicinal herb extracts against poultry strains of Salmonella. Am. Eurasian J. Agric. Environ. Sci. 6 (1):12-15.

Donoghue, D. G. 2003. Antibiotic residues in poultry tissues and eggs. Human health concerns. Poultry Science, 82(4): $618-621$.

European Commission, 2003. Regulation (EC) N $1831 / 2003$ of the European Parliament and of the Council of 22 September 2003 on additives for use in animal nutrition. Official EU Journal.

Engberg, R.M., Jensen, B.B., Hojberg, O. 2007. Plant of the Juglandaceae family as alternative to antibiotic growth promoters in broiler production. Proceedings of the 16th European Symposium on Poultry Nutrition, Strasbourg, France, 26-30 August, 2007 pp. 293-296.

Figueiredo, A.C., Barroso, J.G., Pedro, L.G., Scheffer, J.J.C. 2008. Factors affecting secondary metabolite production in plants. Flavour Fra. J. 23: 213-226.

Florou-Paneri, P., Giannenas, I., Christaki, E., Govaris, A., Botsoglou, N.A. 2006. Performance of chickens and oxidative stability of the produced meat as affected by feed supplementation with oregano, vitamin $\mathrm{C}$, vitamin $\mathrm{E}$ and their combinations. Arch. Geflugelkd. 70:232-240.

Freeman, F., Kodera, Y. 1995. Garlic chemistry: stability of S-(2- propenyl) 2-propene-1sulfinothioate (allicin) in blood, solvents, and stimulated physiological fluids. J. Agric. Food Sci. 43: 2332-2338.

Franco-Jimenez, D.J., Scheideler, S.E., Kittok, R.J., Brown-Brandl, T.M., Robeson, L.R., Taira, H., Beck, M.M. 2007. Differential effects of heat stresss in three strains of laying hens. Applied Poult. Res., 16: 628-634.

Guvenc, A., Koyuncu, M. 1994. A study on the main active compounds of leaves and fruits of Rhus coriaria L. Turkish Journal of Medical Sciences, 20: 11-13.

Greathead H. 2003. Plants and plants extracts for improving animal productivity. Proceedings of the Nutrition Society, 62: 279-290.

Gardzielewska, J., Pudyszak, K., Majewska, T., Jakubowska, M., Pomianowski, J. 2003. Effect of plant-supplemented feeding on fresh and frozen storage quality of broiler chicken meat. EJPAU 6(2). http://www.ejpau.media.pl/series/volume6/issue2/an imal/art-12.html

Guo, F.C., Williams, B.A., Kwakkel, R.P., Li, H.S., Li X.P., Luo, J.Y., Li, W.K., Verstegen, M.W. 2004. Effects of mushroom and herb polysaccharides, as alternatives for an antibiotic, on the cecal microbial ecosystem in broiler chickens. Poult. Sci., 83: 175182. 
Guo, F.C., Kwakkel, R.P., Williams, B.A., Parmentier, H.K., Li, W.K., Yang, Z.Q., Verstegen, M.W. 2004. Effects of mushroom and herb polysaccharides on cellular and humoral immune responses of Eimeria tenella-infected chickens. Poult. Sci., 83: 1124-1132.

Hashemi, S.R., Zulkifli, I., Zunita, Z., Hair-Bejo, M., Loh, T.C., et al., 2009. Effects of dietary supplementation with Euphorbia hirta and acidifier on performance and Salmonella colonization in broiler chickens. Proceedings of the 30th Malaysia Society of Animal Production Annual Conference, June 2-5, Kota Kinabalu, Malaysia, pp: 69-70.

Jagetia, G. C., Baliga, M. S., Venkatesh, P., Ulloor, J. N. 2003. Influence of ginger rhizome (Zingiber officinale Rose) on survival, gluthathione and lipid peroxidation in mice after whole body exposure to gamma radiation. Radiation Research, 160:584-592.

Joke, S., Susan, A. 2007. Beverage of Champaign. http//tune-blog.com.

Kamel, C. 2000. A novel look at a classic approach of plant extracts. Feed Mix. 11: 19-21.

Lopez-Bote, L. J., Gray, J. I., Gomaa, E.A., Flegal, C.I. 1998: Effect of dietary administration of oil extracts from rosemary and sage on lipid oxidation in broiler meat. Br. Poult. Sci. 39, 235-240.

Khan, R.U., Nikousefat, Z., Tufarelli, V., Naz S., Javdani, M.. Laudadio, V. 2012. Garlic (Allium sativum) supplementation in poultry diets: Effect on production and physiology. World Poultry Sci. J. 68: 417-424.

Kim, T.J. 1996. Korean Resource Plants, Vol. II. Seoul National University Press, Seoul, Korea. Pp: 292 297.

Lee, J.C., Kim, J., Jang, Y.S. 2003. Ethanol eluted extract of Rhus verniciflua Stokes inhibits cell growth and induces apotosis in human lymphoma cells. Journal of Biochemistry Molecular Biology, 36: 337-343.

Mathivanan, R., Kalaiarasi, K., 2007. Panchagavya and Andrographis panculata as alternatives to antibiotic growth promoters on haematological, serum biochemical parameters and immune status of broilers. Journal Poultry Science., 44(2):198-204.

Mehrdad, M. 2009. Validated high throughput HPLC method for the analysis of flavonol aglycones myricetin, quercetin, and kaempferol in Rhus coriaria L. using a monolithic column. Journal of AOAC International, 92: 1035-1043.
Nisha, A.R. 2008. Antibiotic residues: A global health hazard. Vet. World. 1 (12): 375-377.

Navid, J., Mozaffar M., Kazem, K. 2013. Effect of dietary medicinal herbs on performance, egg quality and immunity response of laying hens. Adv. Env. Biol. 7(13): 4382-4389.

NOAH (National Office of Animal Health), 2001. Antibiotics for animals. www.noah.co.uk /antibiotics//htm.

Ozcan, M.M., Akbulut, M. 2007. Estimation of minerals, nitrate and nitrite contents of medicinal and aromatic plants used as spices, condiments and herbal tea. Food Chemistry, 106: 852-858.

Platel, K., Srinivasan, K. 2000. Influence of dietary spices and their active principles on pancreatic digestive enzymes in albino rats. Nahrung, 44: 4246.

Symposium on Poultry Nutrition, Strasbourg, France. European Commission. 2003. Regulation (EC) N $1831 / 2003$ of the European Parliament and of the Council of 22 September 2003 on additives for use in animal nutrition. Official EU Journal.

Schleicher, A., Fritz, Z., Kinal, S. 1998. Zastosowanie wybranych ziół w mieszankach treciwych dla kurczt rzenych [The use of some herbs in concentrates for broiler chickens]. Rocz. Nauk. Zootech. 25(3): 213244 (in Polish).

Rababah, T.M., Hettiarachchy, N.S., Horax, R. 2004. Total phenolics and antioxidant activities of fenugreek, green tea, black tea, grape seed, ginger, rosemary, gotu kola, and ginkgo extracts, vitamin E, and tertbutylhydroquinone. Journal of Agriculture, Food and Chemistry, 52: 5183-5186.

Soltan, M.A., Shewita, R.S., El-Katcha, M.I. 2008. Effects of dietary anise seeds supplementation on growth performance, immune response, carcass traits and some blood parameters of broiler chickens. Int. J. Poult. Sci. 7: $1078-1088$.

Windisch, W.M., Schedle, K., Plitzner, C., Kroismayr. A. 2008. Use of phytogenic products as feed additives for swine and poultry. J. Anim. Sci. 86 (E. Suppl.): $140-148$.

Zalacain, A., Prodanov, M., Carmona, M., Alonso, G.L. 2003. Optimisation of extraction and identification of gallotannins from sumac leaves. Biosystems Engineering, 84(2): 211-216. 